\title{
CLIMATE CHANGE OBSERVATIONS AND TRENDS OVERVIEW: FOCUS ON MOROCCO WITH A CASE-STUDY OF A FUTURE RESERVOIR'S RESPONSE TO CLIMATE CHANGE
}

\author{
Wafae EL HARRAKI ${ }^{1, *}$, Driss OUAZAR ${ }^{2}$, Ahmed $^{\text {BOUZIANE }}{ }^{1}$ and Driss HASNAOUI ${ }^{3}$ \\ ${ }^{1}$ Ecole Mohammadia d'Ingénieurs-Mohammed V University, Rabat, Morocco. \\ ${ }^{2}$ Mohammed VI Polythechnic University, Benguerir, Morocco. \\ ${ }^{3}$ Ministry of Equipement, Transport, Logistics and Water, department of Water. Morocco
}

\begin{abstract}
Climate change impacts are being unequivocal on societies, natural resources and economic development. Observations and trends of climate features have been tackled by many scientists through analysis of historical series of temperature and precipitation and projections of theses parameters and of their extremes under different scenarios. This paper gives an overview of climate change observations and trends based on some latest works with focus on impacts on water resources and specifically in Morocco belonging to a vulnerable continent to climate change and to the Mediterranean region qualified as a "hot spot". A case-study from Sebou Basin was conducted through an assessment of water supply from a future reservoir for different sizes under climate change scenarios for the mid and end of the 21 st century. Simulations of the future multi-objective dam showed a decrease of total average supply between $9 \%$ to $12 \%$ for the mid-term scenario and $20 \%$ to $27 \%$ for the long-term scenario. The biggest size was found to have better reliability permitting approaching the fulfillment of all water needs for the log-term. Some adaptation options are recommended in occurrence water demand management, reservoir operation optimization and raising users 'awareness and participation in climate change adaptation.
\end{abstract}

\section{Introduction}

Climate change represents one of the major threats influencing simultaneously humans, ecosystems, natural resources and socio-economic life. The increase of temperature over the world is one of the prominent aspects of climate change. Indeed, the last 30 years (1983-2012) represents the warmest period known since 1400 years in the northern hemisphere according to the Intergovernmental Panel on Climate Change [1] and the mean global temperature between 1880 and 2012 has increased by $0.85^{\circ} \mathrm{C}$ as affirmed by the Fifth IPCC Assessment Report.

Precipitations have known different changes over the globe during the last decades. The Mediterranean zone in occurrence has been characterized by a decrease in accumulated precipitations with a range of -5 to $-25 \mathrm{~mm}$ per decade for the period 1951-2010 and more frequent and intense droughts [1].

Climate models confirm the continuity of variations over the current century with different levels depending on greenhouse gas emissions. Considering the intense scenario of emissions RCP 8.5 considered in the Fifth report of IPCC, the Mediterranean zone would know more decrease of precipitations and runoffs combined to an increase of temperature and evapotranspiration.
[2] states that due to the fact that trends of climate change are characterized by several uncertainties related to scenarios of future greenhouse gas emissions, atmospheric concentrations and forcings, global climate models, downscaling, and impact projections models (hydrological or vegetation), it's rather possible to attempt to give a range of plausible projections that lead to different levels of risks that decision makers would deal with.

In this sense, a range of risks of mean annual streamflow variation was presented by [3] taking into account 5 General Circulation Models several (GCMs) and 11 Global Hydrological Models (GHMs). It was also stressed that the Mediterranean region to which belongs Morocco as well as most regions with dry and subtropical climates would have their renewable surface water and groundwater decreased in a significant way. For instance, Morocco's projections show that an important part of the country, especially the northern part, would witness a reduction of the mean annual streamflow between $30 \%$ and $50 \%$ for a global warming of $2^{\circ} \mathrm{C}$ above $1980-2010$.

[4] stated that $50 \%$ of Mediterranean region would witness a decrease in water availability with a median reduction of at least $9 \%$ for $1.5^{\circ} \mathrm{C}$ of temperature increase above pre-industrial levels and at least $17 \%$ for $2^{\circ} \mathrm{C}$ warming.

* Corresponding author: ellharraki.wafae@gmail.com 
Water resources which are vital for socio-economic development and for different sectors, are highly vulnerable to climate change. Water supply, agriculture, industry, tourism are all affected by climate change but at different levels of risks. Given the high dependence of these sectors on water resources, especially agriculture which is the first consumer of freshwater in the MENA (Middle East and North Africa) region, climate change impacts on water resources availability and quality compounded by the continuous demographic growth make these countries and populations highly vulnerable [5]. This has rendered integrated water resources management and water demand management two priority components of an adaptive water management policy in a context of changing climate caused either by anthropogenic factors or climate variability.

This paper presents a summarized overview of the latest works found in the literature concerning the variability of climate parameters (precipitation and temperature) in Morocco as well as the main findings of projections of these parameters for the coming decades which may help decision makers in integrating these trends for assessing future potential risks, in occurrence on water resources. Some few works found in the literature about climate change impacts on water supply in Morocco are also presented. Additionally, this paper has addressed a case study in Sebou basin of a future multipurpose dam in order to analyze the sensitivity of water supply to climate change impacts and to suggest some options of adaptation.

\section{Climate change impact on water resources in Morocco: Observations and trends}

Located in the North-West of Africa and more precisely in the Mediterranean region, Morocco is characterized by a dominating arid climate in most of its area with a temperate climate toward the northern coasts. During the last decades, the country which is already under water stress, has been marked by more frequent droughts with trends to warmer conditions.

Temperatures and annual precipitations have known considerable variations during the last decades in Morocco. Indeed, according to [6], over the period of 1961-2008, the average temperature have increased by $+0.2^{\circ} \mathrm{C}$ to $+0.4^{\circ} \mathrm{C}$ per decade in different meteorological stations indicating a trend toward warmer conditions.

Concerning annual precipitation variation, the Fifth report of IPCC determines the range of variation in Morocco as well as in the Mediterranean region, between $-5 \mathrm{~mm}$ and $-25 \mathrm{~mm}$ per decade over the period 1951-2010.

[6] have stated, based on the work of [7] that national rainfall amount have been characterized by a decrease of 5\% per decade between 1961 and 2008 taking into account 14 weather stations.

[8] assessed the impact of climate change on water resources of Moulouya basin and found that the observed discharge data registered a decrease over 1958-2000 related directly to the negative trend of total rainfall as well as the positive trend of evapotranspiration.

[9] have focused on the Maghreb countries, for giving an assessment of trends of the precipitation regime based on data of several stations covering 1950-2009 data and comprising the extreme North of Morocco. The trend analysis revealed an increase in dry episodes duration and magnitude, as well as a decrease in the number of wet days and annual precipitation for the Northern of Morocco.

[10] have used data of weather stations located mainly in the northern part of Morocco to assess temperature and precipitation variability for the period 1970-2012. It was remarked that precipitation indices are less significant than temperature except for coastal sites. Mixed spatial patterns were showed with an overall decrease of precipitation apart from few locations in the extreme north which tend to wetter conditions.

In their study of assessment of changes of climatic features over the Arab region, [11], pointed out warming trends for the last 30 years (1981-2011) as well as spatially inconsistent changes and less significant tendency toward wetter conditions characterizing the western part (Algeria, Morocco, and Mauritania) reflected through the variation of the total annual precipitation and the frequency of days with more than $10 \mathrm{~mm}$ of rainfall. This study which has included 9 weather stations for Morocco, has also indicated that regional time series denote relatively wet conditions in the 1960 s with a shift toward drier conditions in the early 1970s.

In addition to analysis of previous variations of the climatic features, many studies have been interested during the last years in the trends of climate for the coming decades in order to afford a certain knowledge to decision makers on the range of climate change impacts based upon different scenarios and models. This could lead to anticipating on mitigation and adaptation actions and reducing the vulnerability to climate change.

In their study focusing on the Mediterranean region and California, and using 30 global climate models (GCMs), [12] have found that projections by 2060-2089 (relatively to the historical period 1960-1989) expect a tendency toward dry climate in the Mediterranean and a decrease of winter precipitation frequency with a domination of the loss by low-medium-intensity precipitation over the gain from extreme precipitation intensifying.

According to the IPCC Fifth Assessment report, an undeniable trend to warming and drying is projected for Morocco for the intense scenario of gas emissions RCP8.5. A trend to increase compared to the period of $1986-2005$ is about $2^{\circ} \mathrm{C}$ to $3^{\circ} \mathrm{C}$ for the mid of the current century (2046-2065) and about 3.5 to $5.5^{\circ} \mathrm{C}$ by the end of century (2081-2100) while it is around 1 to $2^{\circ} \mathrm{C}$ of increase for the RCP2.6. Rainfall for the intense scenario would decrease by $10 \%$ to $20 \%$ in the northern part of Morocco in the mid of 21 st century and by $15 \%$ to $25 \%$ in the end of the twenty first century while a reduction in the southern part for about $10 \%$ would be 
remarked. For the low emission scenario, rainfall tend to decrease in the northern part and to show a slight increase in the southern part without exhibiting a total agreement between models.

[13] showed the impacts of climate change for different degrees of warming $1.5^{\circ} \mathrm{C}, 2^{\circ} \mathrm{C}$ and $4^{\circ} \mathrm{C}$ relative to 1870 1889 , based upon simulations from the Coupled Model Intercomparison Project Phase 5, CMIP5. Temperature is expected to increase in Morocco by 1 to $2^{\circ} \mathrm{C}$, by 2 to $3^{\circ} \mathrm{C}$ and by 4 to $7^{\circ} \mathrm{C}$ for a warming of $1.5^{\circ} \mathrm{C}, 2^{\circ} \mathrm{C}$ and $4^{\circ} \mathrm{C}$ respectively. Precipitation would change by $-20 \%$ to $-40 \%$ for $4{ }^{\circ} \mathrm{C}$ warming in the northern of Morocco and by $-10 \%$ to $-20 \%$ for the other levels of warming.

[6] presented future climatic changes over North African countries using the outputs of the variable resolution of the Global Climate Model ARPEGE (comparing 20212050 to 1971-2000). Winter mean precipitation is projected to decrease by $10 \%$ to $30 \%$ with a small increase during spring in the northern of Morocco ranging from $5 \%$ to $10 \%$ and a warming by 1.2 to 1.8 ${ }^{\circ} \mathrm{C}$. Extreme events are also expected to know some changes consisting of more persistent drought and less high precipitation events.

[14] conducted high resolution simulations (60 Km) forced with the RCP8.5 concentration scenario to project climate changes at global warming of $2^{\circ} \mathrm{C}$ and $1.5^{\circ} \mathrm{C}$ relative to the period of 1981-2010. For Morocco, the percentage of days above the 90th percentile of daily maximum temperature would increase from $20 \%$ to $50 \%$. In addition to that, the drought would be accentuated through the increase of consecutive dry days by 10 to 20 days.

Futures changes in runoff were analyzed by [15] throughout the Regional Initiative for the assessment of Climate Change impacts on water resources and socioeconomic vulnerability in the Arab Region: RICCAR. Regional hydrological modelling results were presented using two hydrological models for RCP 4.5 and RCP 8.5 with a resolution of $50 \mathrm{Km}$ and considering the reference period 1986-2005. Results show an agreement for both hydrological models with some differences in the magnitude on the mean change in annual runoff. In the scenario of RCP 4.5, for the mid-term (2046-2065) and long-term (2081-2100), local runoff in the northern and middle part of Morocco would register a decrease ranging generally from 2 to $6 \mathrm{~mm} /$ month. While for RCP 8.5 , a decrease ranging from 2 to $8 \mathrm{~mm} / \mathrm{month}$ is generally remarked in the north and middle of Morocco for the mid-term while this decrease is exacerbated in the long term ranging from 2 to $10 \mathrm{~mm} / \mathrm{month}$. In terms of percentage of mean runoff change, the Moroccan Highlands are expected to know a decrease for RCP 8.5 up to $32 \%-40 \%$ at the mid of the century which would jump to $48 \%-59 \%$ of decrease by the end of the century. [16] presented results using the dynamic regional climate model ALADIN. These results were in line with the previous trends for Morocco considering the reference period 1971-2005 under the two emission scenarios RCP 4.5 and RCP 8.5. Changes for the future period 20362065 were compared to the reference period. Temperature is expected to rise between 1.2 to $2.4^{\circ} \mathrm{C}$ for Morocco and annual total rainfall is projected to decrease up to $20 \%$ with more persistent extreme drought reflected by the increase in the maximum length of dry spell.

\section{Climate change impacts on water supply in Morocco}

Given these different studies on trends for water resources availability in Morocco for the future decades, an overall tendency toward reduction of precipitation combined with increasing temperature is confirmed for the different scenarios and reference periods taken into account. These trends must be translated into risk assessment studies on water supply and users to anticipate on necessary strategies of adaptation. Few works have tackled the impact on water supply in Morocco due to climate change. However, the interest is increasingly apparent among authors for this kind of studies.

[17] evaluated water supply under two climate change scenarios (the IPCC A2 and B2 scenarios of greenhouse gas concentrations). Using the outputs of the downscaling model SDSM, authors have presented water supply in Rheraya catchment (Tensift Basin) taking into account the demand evolution under climate change scenarios. Adaptation strategies have been assessed for the three horizons 2020, 2050 and 2080 compared to the baseline period (1961-2000) using WEAP, showing that imbalance between demand and supply will be attained in 2053 for scenario B2 and earlier for the conservative scenario A2 (in 2033). It was stressed also that the combination of both adaptation strategies (agricultural efficiency improvement and public awareness enhancement) would not be sufficient to avoid unmet demand in the studied catchment until the end of the current century which affirmed the need for new policies of water management for a more sustainable development.

[18] have analyzed climate variability in Morocco by studying 29 meteorological stations over the country for the period 1961-2007. First analysis of both stations of Essaouira and Marrakech has revealed an increasing trend of temperature as well as an overall decrease in annual rainfall with high variability of precipitation. Other climate change indicators have been analyzed for both stations showing different patterns of climate change for the two cities with the common characteristic of warming and occurrence of drought situations. Comparison of the annual temperature and precipitation of the two decades (1971-1980) and (19982007) has revealed a tendency to global warming (up to $4^{\circ} \mathrm{C}$ ) and to decrease of annual precipitation (up to 42 $\mathrm{mm}$ ) more pronounced in the northern and central area. In terms of future simulations of climate change, and taking as a reference period 1961-1990, the two climate change emission scenarios $\mathrm{A} 2$ and $\mathrm{B} 2$ deriving from the 4th Assessment report of IPCC were studied. Results indicate that an increase of temperature is projected to vary between $0.9^{\circ} \mathrm{C}$ to $1^{\circ} \mathrm{C}$ by $2040,1.8^{\circ} \mathrm{C}$ to $1.9^{\circ} \mathrm{C}$ by 
2070 and between $2.5^{\circ} \mathrm{C}$ to $3.6^{\circ} \mathrm{C}$ by 2099 . In parallel with this, precipitation is projected to decrease by $2.5 \%$ to $4.4 \%$ for the horizon $2040,10.7 \%$ to $11.9 \%$ for 2070 and by $14.8 \%$ to $22.3 \%$ for 2099 . These effects are higher for the Northern part of the country. Authors have also highlighted the tendency to aridity toward the North of Morocco by the end of the current century which affirms the need for actions aiming at reducing the expected gap between water demands and supply.

[19] investigated North African countries' vulnerability to climate change which has led to confirming Morocco's high vulnerability because of its high exposure to climate change combined with its limited adaptation capacities. The study reported that the agricultural sector in Morocco which contributes up to $17 \%$ in GDP and to a relatively high proportion of employment, is likely to know a decrease of production ranging from $15 \%$ to $40 \%$ for the period $2010-2060$.

[20] conducted an assessment study of the vulnerability of water supply in the Middle Draa Valley in South Morocco toward Climate change impacts. Using statistical downscaling models (SDSM software), predictions about temperature and precipitation are consistent with previous reported trends and seem relatively bleak about water availability. Taking as a reference period 1961-2000, the mean temperature is expected to increase under $\mathrm{A} 2$ scenario by 1.4 to $3^{\circ} \mathrm{C}$ for the period $2011-2070$ and by 1.6 to $2.7^{\circ} \mathrm{C}$ under $\mathrm{B} 2$ scenario. Precipitation decrease could reach 5.1 to $15 \%$ for $\mathrm{A} 2$ and 3.9 to $8.9 \%$ for $\mathrm{B} 2$. In addition to the two scenarios, a reference scenario as well as the high rate of population growth scenario were assessed in WEAP resulting in different patterns of water demand evolution with a higher demand for climate change scenarios. Results showed that water availability will be exacerbated between 2010 and 2099 in the Middle Draa Valley knowing more repeated droughts especially for A2 climate change scenario, a high rate of evaporation and less replenishment for the aquifer which is already under decline due to overexploitation. These future projections on water supply guide decision makers in terms of necessary actions toward climate change adaptation especially concerning water demand management and efficiency improvement in this region as well as infrastructure maintenance and nonconventional water resources mobilization.

\section{Case study of water supply sensitivity for a future Moroccan dam}

\subsection{Methodology}

In this section, the sensitivity of a future dam in Sebou Basin to climate change will be assessed. According to [21], sensitivity is "the degree to which a system is affected, either adversely or beneficially, by climate variability or change". As reported by [19], sensitivity to climate change along with exposure to climate change and the adaptive capacity, are the three main components of vulnerability assessment.
Taking into account the previous studies on trends concerning precipitation over Morocco, we assume a reduction of runoff by the mid-term of the 21 st century in the area of the future reservoir of about $15 \%$ and of $30 \%$ by the end of the century. The reliability of releases for three sizes of the studied dam would be assessed under climate change and compared to the reference scenario related to the period (1971-2005) without climate change. This evaluation would be made using the software RIBASIM (RIver BAsin SIMulation) which allows analyzing the behavior of river basins under various hydrological conditions and evaluating different measures related to infrastructure, operational and demand management [22].

The future dam studied in the present paper is Sidi Abbou, located on the river Lebene in Sebou Basin and more precisely in the district of Taounate (fig 1). The main objectives of the future dam are irrigation of a perimeter at its downstream as well as drinking water supply of neighboring centers. This reservoir would also contribute to the protection against floods and its spilled water would be managed jointly with the existing dams on other branches such as Idriss $1 \mathrm{er}$.

Fig. 1. Location of the future dam Sidi Abbou

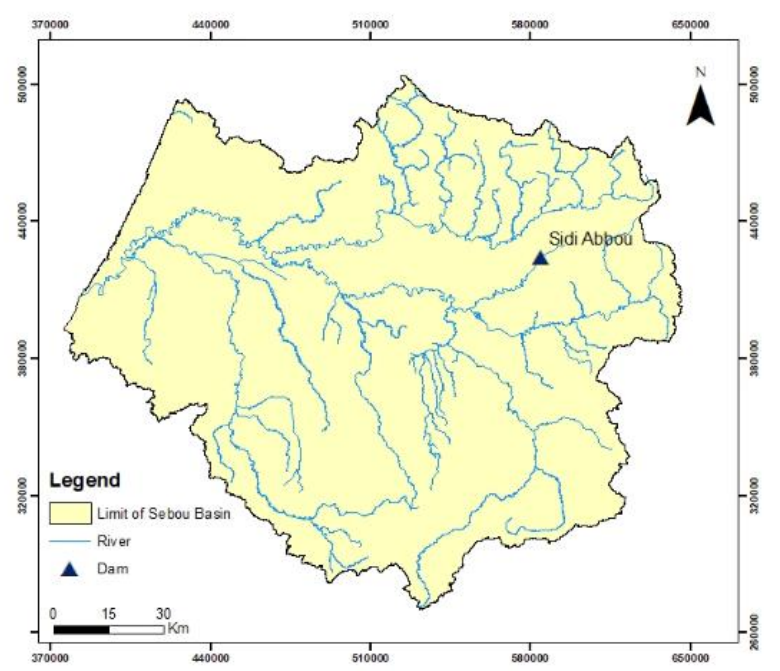

The mean annual inflows of the reservoir are around 87 $\mathrm{Mm}^{3} /$ year for the period 1939-2016.

The future needs for public water supply are taken as a priority use and their annual volume is around 3 Million Cubic Meter $\left(\mathrm{Mm}^{3} / \mathrm{y}\right)$.

Modulation of agricultural water needs were extracted from the planning studies of the reservoir.

The three sizes of the future dam which are evaluated in the present paper are corresponding to heights 350,355 and $360 \mathrm{~m}$ (Table1).

Table 1. Level-Surface-Volume for Sidi Abbou reservoir

\begin{tabular}{|c|c|c|}
\hline $\begin{array}{c}\text { Height } \\
\text { (m) }\end{array}$ & $\begin{array}{c}\text { Surface } \\
\text { (ha) }\end{array}$ & $\begin{array}{c}\text { Volume } \\
\text { (Mm3) }\end{array}$ \\
\hline 304 & 0.0 & 0.0 \\
\hline 310 & 28.7 & 0.6 \\
\hline 315 & 87.8 & 3.4 \\
\hline 320 & 176.5 & 9.8 \\
\hline
\end{tabular}




\begin{tabular}{|c|c|c|}
\hline 325 & 250.8 & 20.5 \\
\hline 340 & 453.2 & 72.8 \\
\hline 345 & 534.3 & 97.5 \\
\hline 350 & 617.6 & 126.3 \\
\hline 355 & 711.8 & 159.5 \\
\hline 360 & 833.2 & 198.1 \\
\hline
\end{tabular}

The evaporation rate for the reservoir is assumed to be nearly the same as the existing neighboring dam Idriss 1er (around $1490 \mathrm{~mm} /$ year based on historical data).

Fig. 2. Schematization of the future reservoir and water users in RIBASIM software

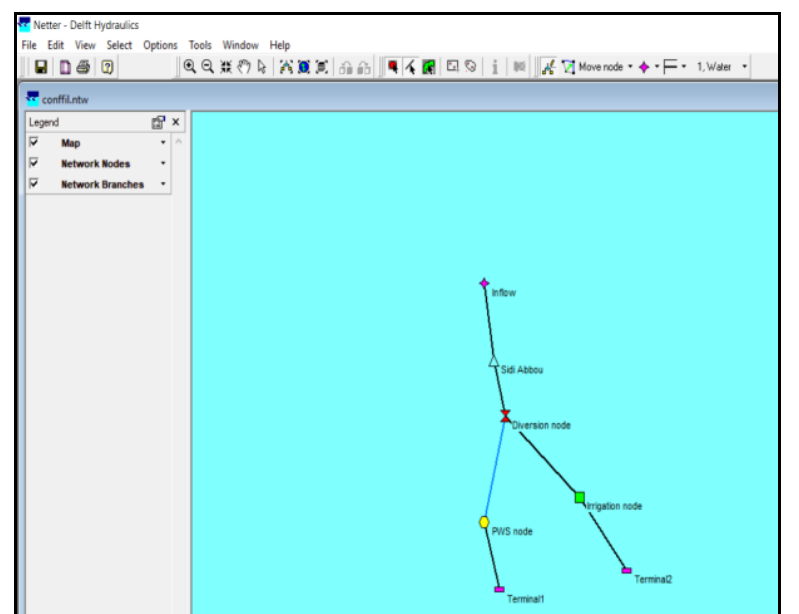

The main equation of calculation of releases from the planned reservoir is basically the balance equation expressed as follows:

$S(\mathrm{t})=I(\mathrm{t})+S(\mathrm{t}-1)-P W S(\mathrm{t})-I R R(\mathrm{t})-\operatorname{Evap}(\mathrm{t})-\operatorname{Spill}(\mathrm{t})$

Where:

- $\mathrm{S}(\mathrm{t})$ : Ending storage in the reservoir for the time period $\mathrm{t}$ (month $\mathrm{t}$ );

- $\quad \mathrm{I}(\mathrm{t})$ : Inflow during the time period $\mathrm{t}$;

- PWS(t): Public Water Supply release during the time period $t$;

- $\quad \operatorname{IRR}(\mathrm{t})$ : Irrigation release during the time period $t$;

- $\operatorname{Evap}(\mathrm{t})$ : The loss by evaporation during the time period $\mathrm{t}$;

- Spill( $\mathrm{t})$ : the overflow that spills during the time period $t$.

\subsection{Results and discussion}

The three simulated scenarios for each size of the future reservoir are "S0: the reference period without climate change", "S1: the mid-term climate change scenario with $15 \%$ reduction of runoff compared to the reference period" and "S2: the long-term climate change scenario with $30 \%$ reduction of runoff compared to the reference period". As reported in the tables below, for the biggest size, the total average supply knows a decrease from 40 $\mathrm{Mm} 3 / \mathrm{y}$ in S0, to $35 \mathrm{Mm} 3 / \mathrm{y}$ for S1 and $29 \mathrm{Mm} 3 / \mathrm{y}$ for S2. Irrigation releases are obtained through simulation with different iterations such as the maximum shortage would be about $50 \%$, the frequency of shortage around $20 \%$ and the average shortage between $7 \%$ and $9 \%$ which reflects indicators aimed by water managers in this context. Given the fact that public water supply, guaranteed at $100 \%$, is about $3 \mathrm{Mm} 3 / \mathrm{y}$, the average supply dedicated to irrigation would vary for the biggest size from $37 \mathrm{Mm} 3 / \mathrm{y}$ for S0, to $32 \mathrm{Mm} 3 / \mathrm{y}$ for S1 and 26 $\mathrm{Mm} 3 / \mathrm{y}$ for $\mathrm{S} 2$. For the medium size, the total average supply will decrease from $36 \mathrm{Mm} 3 / \mathrm{y}$ to $32 \mathrm{Mm} 3 / \mathrm{y}$ and $27 \mathrm{Mm} 3 / \mathrm{y}$ for S0, S1 and S2 respectively with a variation of irrigation releases from $33 \mathrm{Mm} 3 / \mathrm{y}$ to 29 $\mathrm{Mm} 3 / \mathrm{y}$ and $24 \mathrm{Mm} 3 / \mathrm{y}$. For the smallest size studied in this paper, the total average supply will decrease from 30 $\mathrm{Mm} 3 / \mathrm{y}$ to $27 \mathrm{Mm} 3 / \mathrm{y}$ and $24 \mathrm{Mm} 3 / \mathrm{y}$ for S0, S1 and S2 respectively with a variation of irrigation releases from $27 \mathrm{Mm} 3 / \mathrm{y}$ to $24 \mathrm{Mm} 3 / \mathrm{y}$ and $21 \mathrm{Mm} 3 / \mathrm{y}$. From these results, it can be deduced that the total average supply would reduce for the biggest size by $12 \%$ in the midterm and by $27 \%$ in the long term whereas it would decrease for the medium size by $9 \%$ in the mid-term and $23 \%$ in the long term and for the smallest size by $11 \%$ in the mid-term and $20 \%$ in the long term. The patterns of water level in the reservoir show lower levels for S2 and $\mathrm{S} 1$ scenarios compared to S0 scenario due to lower amounts of water reaching the reservoir for climate change scenarios. This would be reflected also by a reduction of water spilled from the reservoir for scenarios S1 and S2. Overall, the irrigation release for the long term climate change scenario corresponding to $30 \%$ reduction of runoff would vary from 21 to 26 $\mathrm{Mm} 3 / \mathrm{y}$. For irrigation needs in the area of the future dam which range from 27 and $30 \mathrm{Mm} 3 / \mathrm{y}$, the biggest size would be barely enough to fulfill this use as well as the domestic water supply for the three scenarios. Hence, pursuing efforts of demand management is extremely substantial and recommended to enhance resilience toward future climate change impacts. Also, efforts of sediment load reduction have to be reinforced in order to preserve reservoir capacity. Another important point that is recommended in this paper is to adapt the reservoir management to climate change scenarios by defining adjusted rule curves to these future trends in order to afford operating policies to water managers and to avoid high shortages. In parallel with these technical options, awareness of users has to be raised toward climate change adaptation concerning water resources.

Table 2. Water supply for the size 1 of Sidi Abbou reservoir for the three studied scenarios

\begin{tabular}{|l|c|c|c|}
\hline \multicolumn{1}{|c|}{ Size 1 (360 NGM) } & S0 & S1 & S2 \\
\hline \multicolumn{4}{|c|}{ Releases for irrigation (Mm3/y) } \\
\hline Average supply & 37 & 32 & 26 \\
\hline Minimal supply & 20 & 18 & 14 \\
\hline Maximal supply & 40 & 35 & 28 \\
\hline Guaranteed supply at 50\% & 40 & 35 & 28 \\
\hline Guaranteed supply at 80\% & 40 & 29 & 23 \\
\hline Guaranteed supply at 90\% & 40 & 23 & 21 \\
\hline Releases for Public Water Supply (Mm3/y) \\
\hline \multicolumn{4}{|c|}{} \\
\hline
\end{tabular}




\begin{tabular}{|c|c|c|c|}
\hline Average supply & 3 & 3 & 3 \\
\hline \multicolumn{4}{|c|}{ Total average supply (Mm3/y) } \\
\hline Average supply & 40 & 35 & 29 \\
\hline
\end{tabular}

Table 3. Water supply for the size 2 of Sidi Abbou reservoir for the three studied scenarios

\begin{tabular}{|c|c|c|c|}
\hline Size 2 (355 NGM) & So & S1 & S2 \\
\hline \multicolumn{4}{|c|}{ Releases for irrigation $(\mathrm{Mm} 3 / \mathrm{y})$} \\
\hline Average supply & 33 & 29 & 24 \\
\hline Minimal supply & 18 & 15 & 13 \\
\hline Maximal supply & 36 & 32 & 26 \\
\hline Guaranteed supply at $50 \%$ & 35 & 32 & 26 \\
\hline Guaranteed supply at $80 \%$ & 29 & 26 & 23 \\
\hline Guaranteed supply at $90 \%$ & 25 & 22 & 20 \\
\hline \multicolumn{4}{|c|}{ Releases for Public Water Supply (Mm3/y) } \\
\hline Average supply & 3 & 3 & 3 \\
\hline \multicolumn{4}{|c|}{ Total average supply (Mm3/y) } \\
\hline Average supply & 36 & 32 & 27 \\
\hline
\end{tabular}

Table 4. Water supply for the size 3 of Sidi Abbou reservoir for the three studied scenarios

\begin{tabular}{|l|c|c|c|}
\hline \multicolumn{1}{|c|}{ Size 3 (350 NGM) } & S0 & S1 & S2 \\
\hline \multicolumn{4}{|c|}{ Releases for irrigation (Mm3/y) } \\
\hline Average supply & 27 & 24 & 21 \\
\hline Minimal supply & 14 & 13 & 11 \\
\hline Maximal supply & 30 & 26 & 23 \\
\hline Guaranteed supply at 50\% & 29 & 26 & 23 \\
\hline Guaranteed supply at 80\% & 26 & 23 & 20 \\
\hline Guaranteed supply at 90\% & 19 & 18 & 17 \\
\hline \multicolumn{3}{|c|}{ Releases for Public Water Supply (Mm3/y) } \\
\hline Average supply & 3 & 3 & 3 \\
\hline Total average supply (Mm3/y) \\
\hline Average supply & 30 & 27 & 24 \\
\hline
\end{tabular}

Fig. 3. Storage at the end of month for the Size 1 of Sidi Abbou reservoir (Scenario 0)

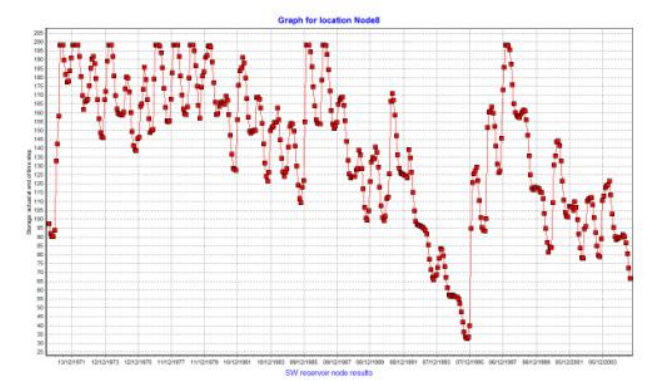

Fig. 4. Storage at the end of month for the Size 1 of Sidi Abbou reservoir (Scenario 1)

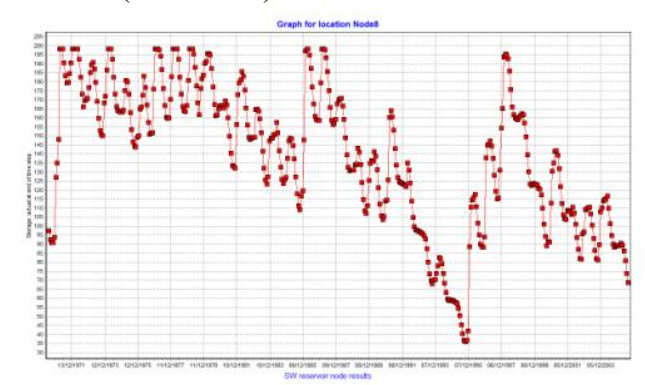

Fig. 5. Storage at the end of month for the Size 1 of Sidi Abbou reservoir (Scenario 2)

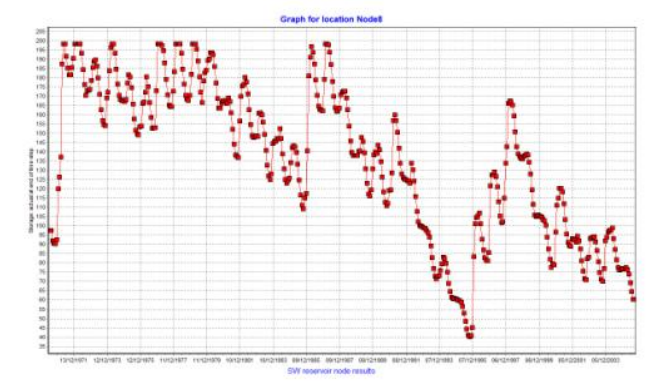

\section{Conclusion}

Climate change observations have revealed variations of precipitation toward decrease in Morocco during the last decades as well as a tendency toward an increase for temperature. Belonging to the Mediterranean region which is often qualified as a hot spot in terms of Climate change known by a tendency to drier and warmer conditions, makes it vulnerable to climate change 'effects. This vulnerability is compounded by population growth and the increasing demand. Trends show a high level of agreement on precipitation's decrease for the future decades as well as on temperature increase especially in the Northern part of Morocco. Levels of changes depend on scenarios and on the reference period taken into account. A case-study of water supply reliability assessment from a future dam in Sebou basin has been conducted for three sizes and two climate change scenarios on inflows. Simulations were set up in RIBASIM software taking into account the domestic water supply as well as irrigation needs related to the future multipurpose dam. With a decrease of runoff for a 
mid-term scenario of about $15 \%$, releases would reduce by $9 \%$ to $12 \%$ whereas a reduction of releases by $20 \%$ to $27 \%$ is characterizing the long-term scenario implying about $30 \%$ decrease of runoff. The biggest size of the reservoir is showing better response to future demands in the long term with slightly less irrigation releases than expressed demand. This paper recommends that technical efforts of adaptation have to be pursued especially those related to water demand management and reservoir capacity preservation through sediment management. Reservoir operation optimization under climate change scenarios is highly recommended to mitigate risks on users. These options have to be coupled with non-technical solutions engaging the different actors of the society in the policy of climate change adaptation and leading to better users' awareness of climate change effects.

\section{References}

1. IPCC: Summary for Policymakers. In: Climate Change 2013: The Physical Science Basis. Contribution of Working Group I to the Fifth Assessment Report of the Intergovernmental Panel on Climate Change [Stocker, T.F., D. Qin, G.-K. Plattner, M. Tignor, S.K. Allen, J. Boschung, A. Nauels, Y. Xia, V. Bex and P.M. Midgley (eds.)]. Cambridge University Press, Cambridge, United Kingdom and New York, NY, USA, (2013).

2. Döll, P., Jiménez-Cisneros, B., Oki, T., Arnell, N. W., Benito, G., Cogley, J. G., Jiang, T., Kundzewicz , Z. W., Mwakalila, Sand Nishijima, A.

Integrating risks of climate change

into water management. Hydrological Sciences Jour nal, 60 (1). pp. 4-13. ISSN 0262-6667 doi:https://doi .org/10.1080/02626667.2014.967250 Available at $\underline{\mathrm{ht}}$ tp://centaur.reading.ac.uk/38974/, (2015)

3. Schewe, J., J. Heinke, D. Gerten, I. Haddeland, N.W. Arnell, D.B. Clark, R. Dankers, S. Eisner, B. Fekete, F.J. Colón-González, S.N. Gosling, H. Kim, X. Liu, Y. Masaki, F.T. Portmann, Y. Satoh, T. Stacke, Q. Tang, Y. Wada, D. Wisser, T. Albrecht, K. Frieler, F. Piontek, L. Warszawski, and P. Kabat, : Multi-model assessment of water scarcity under climate change. Proceedings of the National Academy of Sciences of the United States of America (in press), doi:10.1073/pnas.1222460110, (2014)

4. Schleussner, C.F., T. K. Lissner, E. M. Fischer, J. Wohland, M. Perrette, A. Golly4, J. Rogelj, KChilders, J. Schewe, K. Frieler, M. Mengel, W. Hare, M. Schaeffer. Differential climate impacts for policy relevant limits to global warming: the case of $1.5^{\circ} \mathrm{C}$ and $2{ }^{\circ} \mathrm{C}$. Earth Syst. Dynam. 7, 327-351 (2016).

5. Sowers, J.; Vengosh, A.; Weinthal, E. Climate change, water resources, and the politics of adaptation in the Middle East and North Africa. Clim. Chang, 104, 599-627, (2011)
6. Driouech. F., Ben Rached S., Al Hairech T, Climate variability and change in North African Countries. Chap9, In Climate Change and Food Security in West Asia and North Africa. Mannava V.K. Sivakumar- Rattan Lal Ramasamy Selvaraju - Ibrahim Hamdan Editors. DOI10.1007/978-94007-6751-5. Springer Dordrecht Heidelberg New York London, (2013)

7. Driouech F, Distribution des précipitations hivernales sur le Maroc dans le cadre d'un changement climatique: descente d'échelle et incertitudes (Distribution of Moroccan winter precipitation in the context of climate change). Dissertation, University of Toulouse. http:// www.ethesis.inptoulouse.fr/archive/00001300/01/dri ouech.pdf . Accessed 20 Apr 2012, (2010)

8. Driouech F, Mahé G, Déqué $M$, Dieulin $\mathrm{C}, \mathrm{El}$ Heirech T, Milano M, Benabdelfadel A \& Rouche N. Evaluation d'impacts potentiels de changements climatiques sur l'hydrologie du bassin versant de la Moulouya au Maroc. Global Change: Facing Risks and Threats to Water Resources (Proc. of the Sixth World FRIEND Conference, Fez, Morocco, October 2010). IAHS Publ. 340, (2010).

9. Tramblay Y, El Adlouni S, Servat E Trends and variability in extreme precipitation indices over North Africa. Nat Hazards Earth Syst Sci 13:32353248, (2013)

10. Filahi, S., Tanarhte, M., Mouhir, L., el Morhit, M., Tramblay, Y. Trends in indices of daily temperature and precipitations extremes in Morocco. Theoretical and Applied Climatology, 124(3-4): 959-972, (2016)

11. Donat, M. G., Peterson, T. C., Brunet, M., King, A. D., Almazroui, M., Kolli, R. K., Boucherf, D., AlMulla, A.Y.,Nour, A.Y., Aly, A. A., Nada, T.A. A., Semawi, M. M., Al Dashti, H. A., Salhab, T. G.,El Fadli, K. I., Muftah, M. K., Dah Eida, S., Badi, W., Driouech, F., El Rhaz, K., Abubaker, M. J. Y., Ghulam, A. S., Erayah, A. S., Mansour, M. B., Alabdouli, W. O., Al Dhanhani, J. S. and Al Shekaili, M. N. Changes in extreme temperature and precipitation in the Arab region: long-term trends and variability related to ENSO and NAO. Int. J. Climatol., 34: 581-592. doi: 10.1002/joc.3707, (2014)

12. Polade S. D., A. Gershunov, D. R. Cayan, M. D. Dettinger, D. W. Pierce, Precipitation in a warming world: Assessing projected hydro-climate changes in California and other Mediterranean climate regions. Scientific Reports 7: 10783. DOI:10.1038/s41598-017-11285-y, (2017)

13. Knutti R., J. Rogelj, J. Sedlácek, E. M. Fischer, $A$ scientific critique of the two-degree climate change target. NATURE GEOSCIENCE. DOI: 10.1038/NGEO2595, (2015)

14. Betts R. A., L. Alfieri, C. Bradshaw, J. Caesar, L. Feyen, P. Friedlingstein, L. Gohar, A. Koutroulis, K. Lewis, C. Morfopoulos, L. Papadimitriou, K. J. Richardson, I. Tsanis, K. Wyser, Changes in climate 
extremes, fresh water availability and vulnerability to food insecurity projected at $1.5^{\circ} \mathrm{C}$ and $2^{\circ} \mathrm{C}$ global warming with a higher-resolution global climate model. Phil. Trans.R.Soc.A376:20160452. http://dx.doi.org/10.1098/rsta.2016.0452, (2018)

15. United Nations Economic and Social Commission for Western Asia (ESCWA) et al.. Arab Climate Change Assessment Report - Main Report. Beirut, E/ESCWA/SDPD/2017/RICCAR/Report.

www.unescwa.org/publications/ riccar-arab-climatechange-assessment-report, (2017)

16. Driouech F., El Rhaz K. ALADIN-Climate projections for the Arab region. Arab Climate change assessment report, United Nations Economic and Social Commission for Western Asia 'ESCWA) et al. (2017). Main report. E/ESCWA/SDPD/2017/RICCAR/Report, (2017)

17. Rochdane, S.; Reichert, B.; Messouli, M.; Babqiqi, A.; Khebiza, M.Y. Climate Change Impacts on Water Supply and Demand in Rheraya Watershed (Morocco), with Potential Adaptation Strategies. Water, 4, 28-44, (2012)

18. Ait Brahim, Yassine \& Saidi, Mohamed El Mehdi \& Khaoula, Kouraiss \& Sifeddine, A \& Bouchaou, Lhoussaine.. Analysis of observed climate trends and high resolution scenarios for the 21st century in Morocco. Journal of Materials and Environmental Science. 8. 1375-1384, (2017)

19. Schilling, J., Freier, K. P., Hertig, E., and Scheffran, J.: Climate change, vulnerability and adaptation in North Africa with focus on Morocco, Agr. Ecosyst. Environ. 156, 12-26, (2012).

20. Karmaoui A., Minucci G., Messouli M., Khebiza M.Y., Ifaadassan I., Babqiqi A., Climate Change Impacts on Water Supply System of the Middle Draa Valley in South Morocco. In: Behnassi M., Pollmann O., Gupta H. (eds) Climate Change, Food Security and Natural Resource Management. Springer, Cham, (2019)

21. IPCC, Climate change 2007. In: Climate Change Impacts Adaptation and Vulnerability. Contribution of Working Group II to the Fourth Assessment Report of the Intergovernmental Panel on Climate Change. Cambridge University Press, Geneva., (2007)

22. https://www.deltares.nl/en/software/ribasim/ 